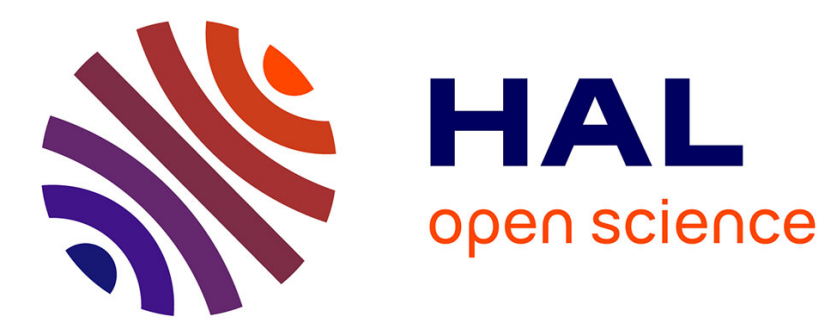

\title{
A sustainable urban logistics dashboard from the perspective of a group of operational managers
}

\author{
Joëlle Morana, Jesus Gonzalez-Feliu
}

\section{To cite this version:}

Joëlle Morana, Jesus Gonzalez-Feliu. A sustainable urban logistics dashboard from the perspective of a group of operational managers. Management Research Review, 2015, 38, pp.1068 - 1085. 10.1108/MRR-11-2014-0260 . hal-01408416

\section{HAL Id: hal-01408416 https://hal.science/hal-01408416}

Submitted on 4 Dec 2016

HAL is a multi-disciplinary open access archive for the deposit and dissemination of scientific research documents, whether they are published or not. The documents may come from teaching and research institutions in France or abroad, or from public or private research centers.
L'archive ouverte pluridisciplinaire HAL, est destinée au dépôt et à la diffusion de documents scientifiques de niveau recherche, publiés ou non, émanant des établissements d'enseignement et de recherche français ou étrangers, des laboratoires publics ou privés.

\section{(ㅇ)(1) $\$$}

Distributed under a Creative Commons Attribution - NonCommercial - NoDerivatives| 4.0 


\title{
A sustainable urban logistics dashboard from the perspective of a group of operational managers
}

Joëlle Morana ${ }^{1}$, Jesus Gonzalez-Feliu ${ }^{2}$

${ }^{1}$ Laboratoire d'Economie des Transports, Université Lyon 2, 14 Avenue Berthelot, 69363 Lyon Cedex 07, France

${ }^{2}$ EVS-PIESO, Institut Henri Fayol, Ecole Nationale Supérieure des Mines de Saint-Etienne, 158 cours Fauriel, 42023 Saint-Etienne Cedex 02, France

\begin{abstract}
The aim of this paper is to propose a sustainable dashboard for evaluating the sustainable performance of urban delivery systems, from the perspective of operational logistics managers, one of the categories of stakeholders given less consideration by public authorities in their quest for consensus.

First, a synthesis of the main works on the subject is proposed, in order to provide a common grid of economic, environmental and social/societal indicators for Sustainable Supply Chain Management, after which the method for defining the dashboard is presented. This method is derived from a collaborative decision-support approach and applied to a panel of operational logistics managers. Using a co-constructive method, a group of experts is consulted first separately then by small groups, then a group restitution and consensus search process is made to find an agreed set of indicators.

The results show a difference between the indicators chosen in the individual phase and those defined in small groups. They show also a gap between classical expert-obtained indicators (mainly made by one or a small group of non-operational experts) and the proposed dashboard, made by and for operational managers.

The originality of the paper is that it addresses two issues (urban logistics evaluation and consensus search) by using methods of natural and active pedagogy, and shows by an experimental method the interests and opportunities of collaboration in defining sets of indicators for urban logistics evaluation.
\end{abstract}

Keywords: Sustainable Supply Chain Management; urban logistics; sustainability dashboard; collaborative decision making; consensus. 


\section{A sustainable urban logistics dashboard from the perspective of a group of logistics managers}

\section{Introduction}

The sustainability of Supply Chain Management is becoming increasingly important for organizations that want to gain a competitive advantage, and for industries sensitive to environmental problems or social issues (Svensson, 2007; Carter and Rogers, 2008; Seuring and Müller, 2008; Pagell and Wu, 2009; Morana, 2013). However, although these issues of sustainability are coming under greater theoretical and practical scrutiny (ecodesign, waste management, life-cycle assessments, etc.), the management and measurement of sustainability performance over their whole supply chains are given too little attention. Nonetheless, sustainability issues in supply chains have become an important topic in the strategic management of organizations and the adoption of a sustainable Supply Chain Management requires that particular attention be focused on performance management, accounting, auditing and management control. In our view, the design of a sustainable dashboard is a tool that can be used to encourage the practice of sustainable Supply Chain Management and allow stakeholders to discriminate positively in favor of sustainable products and services.

The need in companies to gather data, make information available, and generate knowledge for decision-making has never been stronger. Although economic indicators remain major concerns, the measurement and management of the social and environmental performance of complete supply chains are becoming steadily more central to the work of firms. The good reputation of a firm is increasingly linked to the elimination of forced labor and/or child labor. Also, the certification of "green" processes, products and services is a feasible means of supporting economic recovery. However, this requires reliable and clear key sustainability performance indicators.

The organizational aspects of urban logistics schemes in the global sustainable supply chain must be considered (Allen and Browne, 2010). Indeed, as urban traffic increases, some organizations are faced with the problem of efficient urban freight distribution. Additional constraints include relations with public authorities which apply different criteria for managing products flows (i.e. no deliveries to the city-center by modes of transport considered highly pollutant).

The aim of this paper is to examine the use of indicators by private organizations in the context of sustainable urban supply chains, while considering the constraints of public actors. To do this we first provide a synthetic review of the literature to present the main principles of sustainable urban Supply Chain Management and its links with the global supply chain. Secondly, we assess the importance of performance measurement in sustainable urban logistics. Thirdly, we propose a dashboard with a set of indicators, designed on the basis of an investigation conducted with logistics professionals. Finally, we discuss these results and present further developments in a near-future perspective.

\section{Literature review: from the performance measurement of Sustainable Supply Chain Management (SSCM) to Urban SSCM}

\subsection{Taking into account the managerial interest of Sustainable Supply Chain Management}

While the contribution of Supply Chain Management (SCM) is becoming ever more significant, it does not stop at the economic aspect. It can also to be found in ecosystem preservation. The same is true of social and societal recognition of the actors who make up the supply chain. It is therefore becoming appropriate to speak of Sustainable Supply Chain Management (SSCM), which is akin to Sustainable Development (Morana, 2013).

Historically, French research dedicated to Sustainable Supply Chain Management initially focused on reflections on the notion of freight transport: maritime or fluvial (Collin, 2003; Rodrigue et al., 2010) and especially road (Bernadet, 2008; Bazin and Beckerich, 2008; Blanquart and Carbone, 2008, Blanquart and Burmeister, 2009). It was then logical from the urban standpoint that attention was paid to the prominent economic/environmental aspect: high cost due to frequent stops correlated with growing pollution (Ségalou et al., 2004; Gonzalez-Feliu and Morana, 2010; Dablanc and Rakotanarivo, 2010; Gonzalez-Feliu et al., 2012). The perspective then shifted to improving collaborative logistics practices (Gonzalez-Feliu et al., 2013; Carbone and Blanquart, 2014).

Regarding research published in English in the period 2007-2009, several studies focused on a review of work on the Sustainable Supply Chain Management, in order to define a conceptual framework and a generic definition. Several definitions were provided, such as:

"SSCM requires a broadened approach of SCM. It should emphasize economic, ecological and social aspects of business practices and theory." (Svensson, 2007); 
- $\quad$ "we define SSCM as the strategic, transparent integration and achievement of an organization's social, environmental, and economic goals in the systemic coordination of key interorganizational business processes for improving the long-term economic performance of the individual company and its supply chains." (Carter and Rogers, 2008);

- "we define Sustainable Supply Chain Management as the management of material, information and capital flows as well as cooperation among companies along the supply chain while taking goals from all three dimensions of sustainable development, i.e., economic, environmental and social, into account which are derived from customer and stakeholder requirements. " (Seuring and Müller, 2008);

- "To be truly sustainable a supply chain would at worst do no net harm to natural or social systems while still producing a profit over an extended period of time; a truly sustainable supply chain could, customers willing, continue to do business forever.[...] A sustainable supply chain is then one that performs well on both traditional measures of profit and loss as well as on an expanded conceptualization of performance that includes social and natural dimensions" (Pagell et Wu, 2009);

In line with these works, we consider the definition of Morana (2013): "Sustainable Supply Chain Management can be understood as the management of the flows of materials, information, capital, people and intelligence with an economic, environmental and social/societal goal. As a strategic management approach, it can be found in the quite deliberate set of intra- and inter-organizational connections, in view to ensuring the long-term performance of each company and of its supply chain."

These developments show that Sustainable Supply Chain Management has become a strategic issue for firms. But it must be clear that its success depends on the ability to clearly connect each economic, environmental and social/societal element. Consequently, we built a chart (see figure 1) in which we can find paths for the coherent implementation of SSCM: 
Figure 1 - Paths of Sustainable Supply Chain Management, adapted from Morana, 2013

Green operations

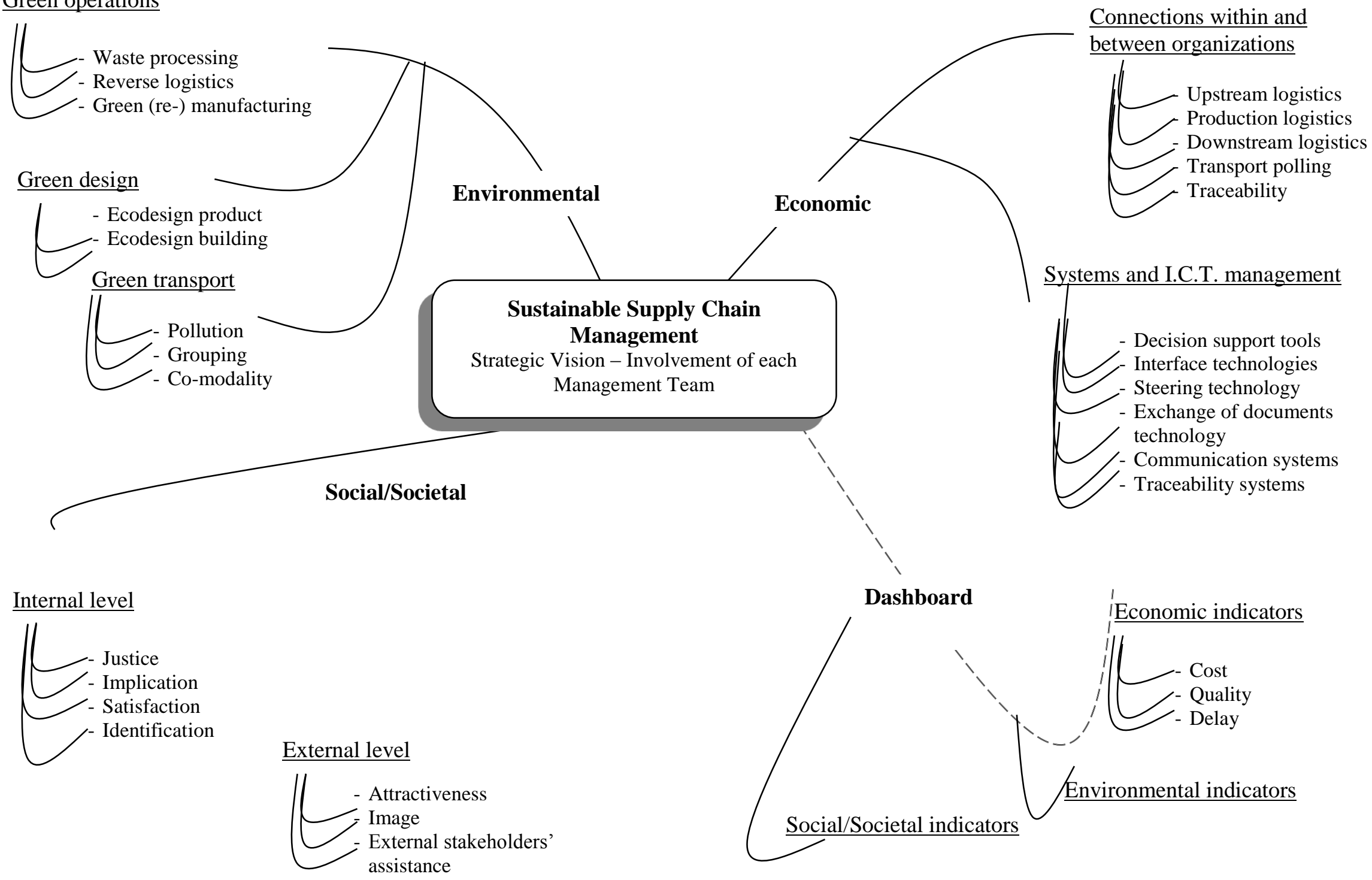


To operate, SSCM requires the conjunction of three elements, i.e. economic, environmental and social/societal while the measurement of its performance can be established by implementing dashboard(s):

- the application of SSCM from the economic standpoint is based mainly on intra- and interorganizational connections. These connections have an impact on the "three basic logistics" which are often outlined in the description of the logistical strategy: upstream, production (internal) and downstream stages. But in a long-term framework, other elements need to be developed like strategic transport management (transport pooling, urban logistics space management), the role of the logistics providers, the traceability approach and, of course, information and communication technologies used to facilitate these connections;

- the strategic importance of environmental SSCM has become a crucially important element. The article by Srivastava (2007) provides an interesting insight into green logistics. We enriched this work (Morana, 2013) and considered three main focal areas: green design and eco-design with the latter integrated in processes and building; green operation with actions in green manufacturing and remanufacturing, waste management such as electrical and electronic equipment waste management $^{1}$ and reverse logistics; and thirdly, green transport with actions to promote multimodality, the use of vehicles considered non or less-pollutant, eco-conduct and eco-taxes;

- it is crucial to link (internal and external) human resources and logistics. Although human aspects are often highlighted in (Green) Supply Chain Management, the interest of specifying these aspects clearly has become appropriate. In line with the work of Gond (2006) who examined human resources in Sustainable Development, we propose two main focal areas for sustainable logistics. Firstly, in an internal context with particular emphasis given to four aspects: individual rights with for example- the implementation of the SA8000 standard ${ }^{2}$; organizational commitment which focuses on the recognition of competence, motivation, training, etc.; organizational identification; and, finally, job satisfaction. Secondly, in an external context, we highlight the role of the company's attractiveness, reputation and image (for instance, the implementation of the IS0 14000 standard and traceability), and the support of unions and external partners.

To conclude this paragraph, we must not forget "performance measurement" which, as is generally recognized, falls under the adage "we can only manage what we can measure". In our view, as a decisionsupport measuring tool, performance measurement is one of the most influential factors of the "dashboard". In logistics, this tool must highlight financial (linked to a financial type balance sheet) and non-financial indicators (qualitative indicators). In SSCM, the dashboard presents economic data (cost, but also according to us, quality and delay for logistics), and environmental (pollution, for instance) and social/societal (rate of absenteeism and customer satisfaction) data.

\subsection{Sustainable Supply Chain Management and Urban logistics}

Although all the links in the supply chain are important, it is necessary to underline the value of urban logistics or "last-mile logistics". Indeed, logistics in close connection to customers' needs has always been an important element in the supply chain (Mossman and Morton, 1965), and the growth of e-commerce only reinforces this fact. Thus FEVAD (Fédération des Entreprises de Vente A Distance - Federation of Remote Sales Companies) has reported an increase in online sales in Europe in $2012^{3}$. In terms of logistics, this has consequences for the ways in which orders are prepared and delivered. In addition to the constraints of private actors, it must take into account the requirements of public authorities. Therefore, having a tool that incorporates key performance measures which consider the interests of all market players is essential. Figure 2 presents the approach proposed. This approach specifies the challenges involved in evaluating/maximizing sustainable performance measures of urban flows. To assure good coordination between private and public actors, it is necessary to determine sustainable variables that can be used to represent the interests of each stakeholder. Naturally, the success of an urban Sustainable Supply Chain Management system must consider the interests of the global logistics system. Thus clear understanding of the supply chain concerned is also needed.

\footnotetext{
${ }^{1}$ Decree no. 2005-829 of 20 July 2005 (Official Gazette no. 22)

2 The SA8000 standard was drawn up in 1997 by an American organization: SAI (Social Accountability International). It relies upon human rights reference texts. It is based on the conventions signed by the International Labor Organization (ILO), the Universal Declaration of Human Rights published by the United Nations (UN) and the UN Convention on the Rights of the Child.

${ }^{3}$ http://www.fevad.com/uploads/files/Publications/Chiffres Cles 2013(1).pdf. In 2012, the European e-commerce annual turnover was $€ 312$ Billion.
} 
Figure 2 - Urban logistics in a sustainable global logistics system

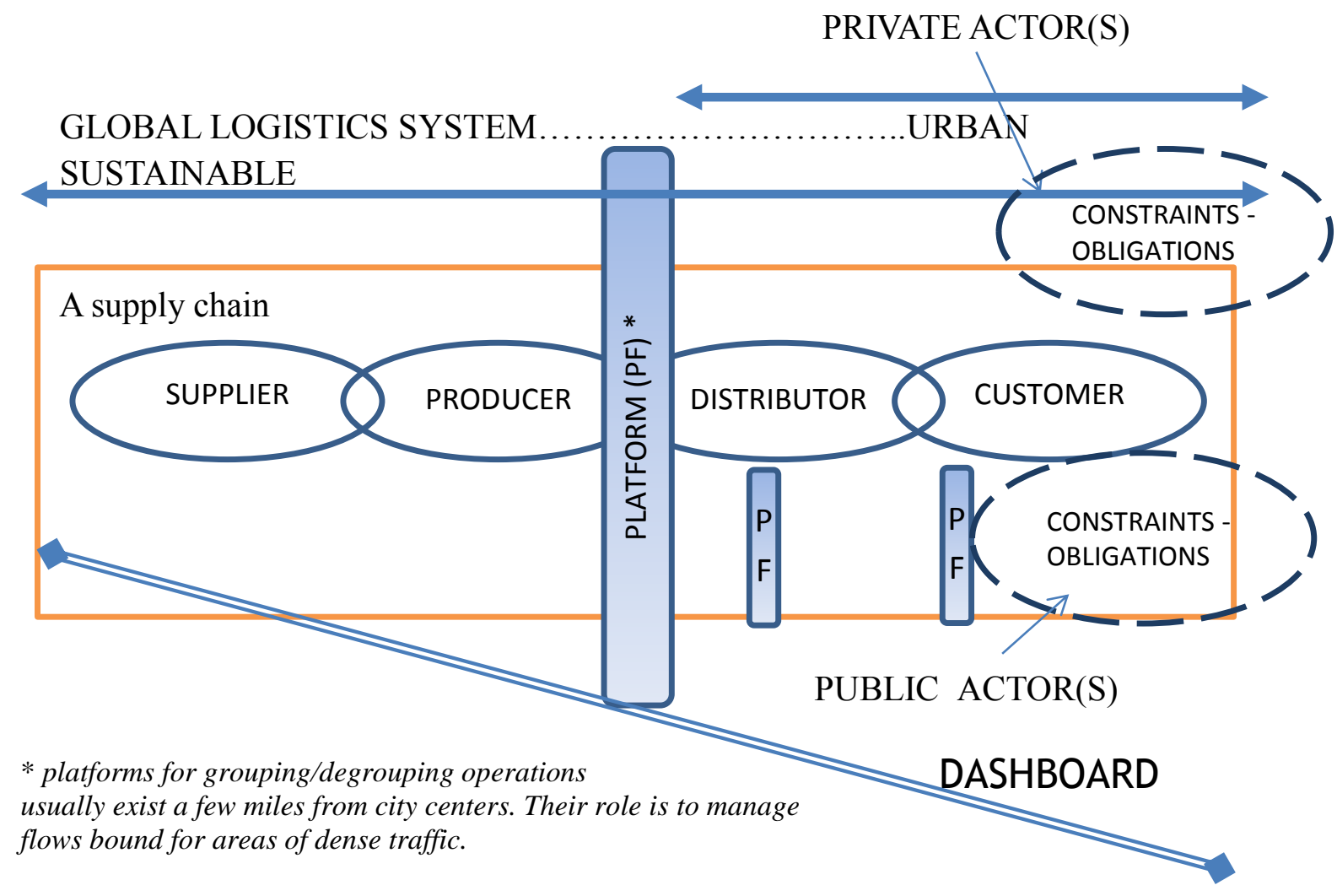

\subsection{Key Performance Indicators in Sustainable (Urban) SCM}

In logistics, the aim of measuring performance is in general directly linked to a goal of ensuring permanent improvement that leads to the conceptualization and implementation of measurement systems combining diagnostics and decision-aids. If we focus on evaluating Supply Chain Management (SCM) with Key Performance Indicators (KPI), we find two interesting references on the subject: (1) the work of Gunasekaran and Kobu (2007), with a list of 26 indicators; and (2) the work of Griffis et al. (2007) with 14 indicators. Although these lists do not include any environmental indicator, while social indicators are over-represented, they can be used as a basis for an initial sustainability evaluation (Morana, 2013).

Regarding the context of measuring sustainable urban logistics from the standpoint of a private company, Morana et al. (2014) proposed a set of 28 indicators (14 for economic, 6 for environmental and 8 for social performance) (Cf. Table 1). 
Table 1 - Main indicators for urban logistics sustainability from the standpoint of private companies (Morana et al., 2014)

\begin{tabular}{|c|c|}
\hline \multicolumn{2}{|c|}{ Economic indicators $(N b .=14)$ concern cost, quality and delay } \\
\hline - Distance travelled & - Investment costs \\
\hline - Vehicle load factor & - Operational costs \\
\hline - Warehouse load factor & - Return on investment \\
\hline • Vehicle load path & - Total travel time \\
\hline - Number of parcels at warehouses & - Service rates \\
\hline - Number of delivery points & - Delay respect rates \\
\hline - Number of collection points & - Customer satisfaction rates \\
\hline \multicolumn{2}{|l|}{ Environmental indicators $(\mathrm{Nb} .=6)$} \\
\hline - Greenhouse gas emission rates & - Noise rates \\
\hline - Pollutant gas emission rates (NOx, SOx) & - Road occupancy rates \\
\hline - Solid particles emission rates (PM 10) & - Reverse flow rates \\
\hline \multicolumn{2}{|l|}{ Social/Societal indicators $(\mathrm{Nb} .=8)$} \\
\hline - Absenteeism rates & - Employment creation rates \\
\hline - Stress management rates & - Employment conversion rates \\
\hline • Users' acceptability & - Training rates \\
\hline - Inhabitant satisfaction rates & - Estimation of city's image \\
\hline
\end{tabular}

\section{Methodology}

Using a basic list of indicators, we propose a collaborative decision support methodology in view to formulating a sustainable urban logistics dashboard. This can be done with two prerequisites:

- the first is the consideration of a minimum number of indicators, as recommended by Bouquin (2001). According to this author, as an instrument of action, a dashboard includes a "relatively small number of indicators (five to ten) [integrated] to inform managers of the state and evolution of the systems they control and identify the trends that will influence these systems over a time scale consistent with the nature of their functions" (Ibid, 2001, pp. 397-398);

- the second is the inclusion of three types of measurement that reflect the three dimensions of sustainable development, i.e. economic, environmental and social/societal.

We also try to precise the "stakeholder" quality, i.e. is it an indicator for public (public authorities and/or customer/inhabitants) and/or private actor (supplier, producer and/or distributor).

To answer our question, we propose a method based on active adult pedagogy findings, mainly those of natural pedagogy (Csibra and Gergely, 2009). More precisely, we aim to use a socio-constructive collective method to obtain, by agreement, a dashboard, from a panel of operational managers. The choice of the target individuals has been made because most evaluation methods are based on city logistics experts (Patier and Browne, 2010), public authorities (Lindholm, 2013) or strategic managers (Gonzalez-Feliu and Morana, 2014) but the main stakeholders dealing daily with the constraints and difficulties of the urban logistics field at an operational level are drivers, land crew and operational managers. To have the managerial component, we chose to focus on operational managers.

In order to develop a socio-constructive procedure, the construction of the dashboard has been divided into four stages:

1. The first stage is that of "personal knowledge", in which each involved "expert" choses, from her or his experience, the set of indicators she or he thinks are the most adapted to evaluate urban logistics, considering also her or his expertise field. In this phase, no support is provided to define the indicators: each expert defines them, individually, without any external help or support.

2. The second stage is a first data consolidation phase. From the answers of the experts, a set of indicators is defined, reproducing all indicators given by each expert, but without indicating the frequency of each answer.

3. The third stage is a sub-group construction phase. In other words, the entire group of experts is divided into several homogeneous subgroups that will exchange their experience to define a set of indicators. In this phase, two support documents are provided: a first list containing all indicators identified in the first stage (and consolidated in the second) and a list of indicators provided by city logistics experts (which details are provided in Gonzalez-Feliu and Morana, 2014). 
4. The fourth and last phase is a group decision making phase, in which each subgroup restitutes to the entire group their results, then, once all indicators retained by each group are identified and communicated, a consensus search dialogue is initiated to converge to a set of indicators agreed by the entire group.

This method differs from a basic group-decision process (Yearwood and Stranieri, 2006) in one main point: in a basic group decision making process, decisions are individually made, if possible without interactions with others. This process is followed by a decision communication phase where choices and the importance of using the different indicators were discussed. Third and last, a consensus research phase took place between experts in order to make consensual decisions. In the proposed method, individual decisions are of course made, but then a co-construction phase makes individuals make a first consensual solution search, in subgroups of small size. In this way, the co-construction process accentuates collaboration and the will of finding consensus. The group restitution phase and the need of find a real agreement (i.e. the acceptance of a common decision) instead of a consensus (which, according to Yearwood and Stranieri, 2006, can finish into a non-decision by the impossibility of finding agreements), which guaranteed a final set of indicators.

To illustrate this method, 25 managers have participated to the experimental phase. Those managers belong to three categories, each associated to the type of company they belong to:

- 9 managers belong to the transport (2PL) or logistics service (3PL, 4PL) field: 5 are related to transport management and 4 to freight forwarding.

- 8 to the production and manufacturing field: 4 related to production management and 4 to distribution management.

- $\quad 8$ to the distribution field: 5 related to wholesaling and 3 to integrated distribution.

The experimentation process took place in two different days, between them a time period of 3 days was necessary for data formatting and analysis. The entire process was effectively developed as follows:

1. In the first stage, managers were consulted separately, without the possibility of communicating their results to the others. First, an introduction of 30 minutes about urban logistics and the needs of evaluating and measuring impacts were given to them. After that, each manager had 15 minutes to write a set of 5 to 10 indicators to measure the sustainability of urban logistics solutions. The novelty with respect to other dashboard construction methods is that in this phase, each manager had no external support, so she or he could only count with her or his memory and personal experience. This was done to avoid biasing the data collection process, since giving in the first phase a list of indicators would condition each individual's answers.

2. After collecting all lists of indicators, the second phase started. During the three days between the two meetings, data was checked, standardized, corrected, aggregated and analyzed. The main actions dealt to identify which indicators were similar (although sometimes having different names) and find which indicators were identified by the highest number of managers. With those results, a list of indicators was produced.

3. To prepare the third phase, two lists of indicators were prepared, to support the group decision process. The first list results from the second stage. The resulting indicators were sorted alphabetically to do not give an idea of which measures were the most popular. The second one was obtained by an analysis of the literature, which basis can be found in Morana (2013) and GonzalezFeliu and Morana (2014).

4. Three days after the first meeting, a second meeting was organized. In a first time, the group was divided into 7 subgroups. Note that according to active pedagogy, a subgroup for co-construction purposes needs to have at least 3 individuals. A first phase of 30' was given for individual reflection, in order to prepare the group decision process and complement each manager's choices with the support of the two given lists. Then, during 1 hour, each subgroup discussed about which indicators would be selected. Each subgroup should give a list of 5 to 10 indicators.

5. After that, a group restitution phase took place. During 1 hour, each subgroup explained the reasons of choosing their proposed set of indicators, and presented them. All indicators were noted in a paperboard to show to the group the similarities and differences in their choices.

6. Finally, a group concordance phase took place. Opposing to consensus, the concordance implies finding an agreement by unanimity. It takes more time (in the proposed experimental process, it took about $1 \mathrm{~h}$ ) but at the end all individuals accepted the retained solution. After this phase, a restitution of the given set of indicators was made to the group. 


\section{Results}

This section presents the results of the collaborative decision making procedure. We propose to examine the results after the different steps. After step 1, a total list of 182 answers has been obtained, i.e. that each operational manager has selected 7.3 indicators in average. Overall, 95 different indicators have defined by the total panel of experts, i.e. about 3.8 per individual. This leads to a long list of indicators, most of them identified by one or two individuals. We report in Table 2 the 21 indicators that are identified by at least two experts. We observe that no indicator makes the unanimity. Indeed, only one of the triad indicators (costquality-time), the service rate, is identified by more than half of the group. However, it is identified by only 13 of the 25 experts. The greenhouse gas emission rate, one of the main indicators to measure environmentally of urban logistics, comes in second position, with 12 of the 25 experts proposing it. The logistics costs and the customers' satisfaction rate, also used in classical logistics evaluation, remain popular among the set of experts: they are proposed by respectively 11 and 10 experts. The rest of the indicators are proposed by less than 8 experts. Only 9 indicators are proposed by at least 5 experts, which make about $9.5 \%$ [9/95] of the total number of different indicators. Moreover, 5 indicators are proposed by three experts, 6 by two experts and 71 by only one expert.

Table 2 - Result of steps 1: indicators defined by at least two experts during the individual decision stage.

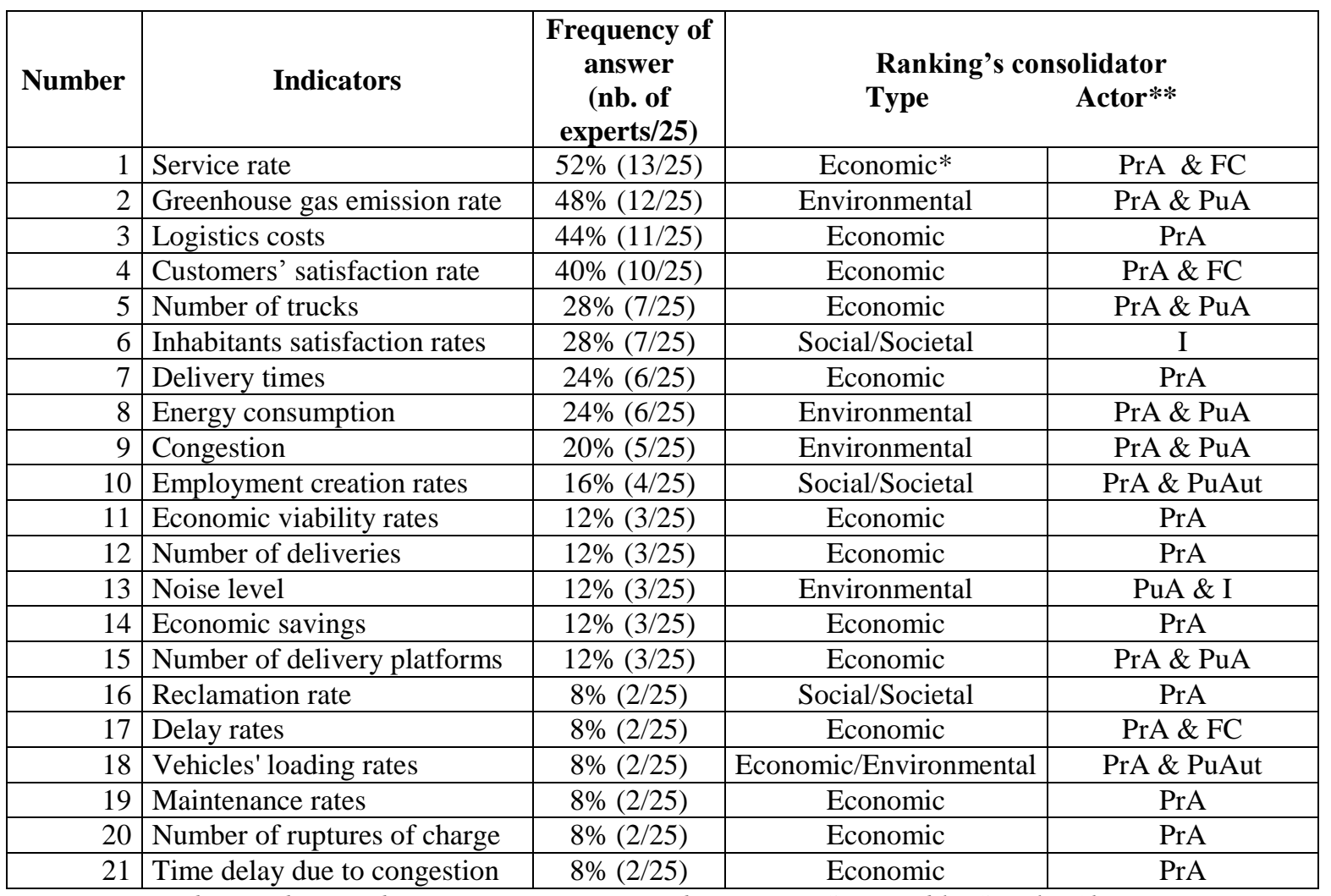

* as a reminder, and according to us, economic indicators in Sustainable Supply Chain Management concern cost, quality and delay.

** PrA: private actors concern firms (supplier, producer and distributor);PuA: public actors; FC: final customer; PuAut: public authorities and I: inhabitant.

It is important to note that the experts did not have any support to define the set of indicators, which make the exercise difficult. However, we observe that, without support or communication, each expert has its vision and a consensus seems far to be reached. For that reason, two sets of indicators were defined during the second stage, without the opinion of experts: the first includes the 95 indicators extracted from the results of the first stage, renaming them when necessary to produce a standard set of indicators; the second comes from the extension of the 75 indicators proposed in Gonzalez-Feliu and Morana (2014) by adding 25 indicators coming from classical accounting and management studies (Morana, 2013), which gives us a set of 100 indicators. 
Those both sets have been given to the group, and the third stage has been launched by dividing the group into 7 subgroups of 4 or 5 experts each. Each subgroup has defined the set of indicators that seemed the more suitable for its members, and then a group restitution procedure (fourth stage) has been animated. To summarize the results and feed the last group decision making phase, all indicators identified by each subgroup have been noted and aggregated to propose the following table:

Table 3 - Identified indicators by each subgroup

\begin{tabular}{|c|c|c|c|c|c|}
\hline \multirow{3}{*}{$\begin{array}{l}\text { Number } \\
1 \\
\end{array}$} & \multirow{2}{*}{ Indicator } & \multirow{2}{*}{$\begin{array}{c}\text { Frequency } \\
\text { of selection } \\
\text { (nb. of } \\
\text { subgroups/7) }\end{array}$} & \multirow{2}{*}{$\begin{array}{c}\text { Rankings } \\
\text { comparison } \\
\text { Table } 2 \text { \& } 3\end{array}$} & \multicolumn{2}{|c|}{ Ranking's consolidator } \\
\hline & & & & Type & Actor \\
\hline & Service rates & $100 \%(7 / 7)$ & $1=>1$ & Economic & PrA \& FC \\
\hline 2 & Customers' satisfaction rates & $100 \%(7 / 7)$ & $4=>2$ & Economic & PrA \& FC \\
\hline 3 & Congestion & $71 \%(5 / 7)$ & $9=>3$ & Environmental & PrA \& PuA \\
\hline 4 & Pollution emission rates & $57 \%(4 / 7)$ & New & Environmental & $P r A \& P u A$ \\
\hline 5 & Operational costs & $57 \%(4 / 7)$ & New & Economic & $\operatorname{Pr} A$ \\
\hline 6 & Monetary savings & $57 \%(4 / 7)$ & New & Economic & $\operatorname{PrA}$ \\
\hline 7 & Customers' evolution & $57 \%(4 / 7)$ & New & Economic & $\operatorname{PrA}$ \\
\hline 8 & Vehicles' loading rates & $43 \%(3 / 7)$ & $18=>8$ & Economic/Env. & PrA \& PuAut \\
\hline 9 & Products' prize & $29 \%(2 / 7)$ & New & Economic & $\operatorname{Pr} A$ \\
\hline 10 & Staff turnover & $29 \%(2 / 7)$ & New & Social/Societal & PrA \& PuAut \\
\hline 11 & Delivery times & $29 \%(2 / 7)$ & $7=>11$ & Economic & $\operatorname{PrA}$ \\
\hline 12 & Number of deliveries & $29 \%(2 / 7)$ & A part of 15 & Economic & $\operatorname{PrA} \& \mathrm{PuA}$ \\
\hline 13 & Average distance per delivery & $14 \%(1 / 7)$ & New & Economic & $\operatorname{PrA}$ \\
\hline 14 & Employees' satisfaction rates & $14 \%(1 / 7)$ & New & Social/Societal & $\operatorname{PrA}$ \\
\hline 15 & $\begin{array}{l}\text { Greenhouse gas emission } \\
\text { rates }\end{array}$ & $14 \%(1 / 7)$ & $2=>15$ & Environmental & $\operatorname{PrA} \& \mathrm{PuA}$ \\
\hline 16 & Logistics reliability & $14 \%(1 / 7)$ & New & Economic & $\operatorname{PrA}$ \\
\hline 17 & $\begin{array}{l}\text { Number of employments } \\
\text { created/destroyed/reconverted }\end{array}$ & $14 \%(1 / 7)$ & A part of 10 & Social/Societal & PrA \& PuAut \\
\hline
\end{tabular}

\section{First comments:}

Firstly, we can compare the result of Tables 2 and 3. As a remember, Table 2 concerns the ranking of indicators by each expert, and Table 3 relates to the consolidation of the 7 subgroups. We notice that only 6 indicators on 21 have been maintained unchanged, and 2 have been partially modified, that is a total of 8 indicators on $21(38 \%)$. We can say that the decision of the group(s) modify(ie) largely the individual decisions. Besides, except for the service rate, indicators of Table 2 change order of ranking. We can also say that the indicators of the Table 3 seem more general, and that it is possible to find a consolidation. For instance, "pollution emission rates" (number 4 - Table 3), "energy consumption" (number 8 - Table 2) and greenhouse gas emissions (number 15 - Table 3) are all related to environmental impacts. For some sources of energy (mainly fuel), energy consumption and greenhouse gas emissions are related, and also for some pollutants (Ségalou et al., 2004). However, it is not always possible to define a unique "environmental impact" indicator but some frameworks, like Life Cycle Analysis, allow to define some generic indicators that identify raw savings satisfactorily. On the economic, environmental and social/societal distribution, we note a "better representativity" of the number of indicators between the tables. So, between the two tables, we pass from $62 \%$ [13/21] to 59\% [10/17] for economic indicators, from 19\% [4/21] to $18 \%$ [3/17] for environmental indicators, from $14 \%$ [3/21] to $18 \%$ [3/17] for social/societal and 1 indicator which has an economic/environmental status for each table.

Now if we compare the Table 3 with the Table 1 of the review of literature (Cf. annex 1), we notice two main differences. First, indicators in connection with the management of warehouse are not evoked by the experts. The experts center rather their interests on the transport and the delivery. Then, the societal level is not finally retained by the experts. They take more a look on the place and the role of employee in the firm. In the end we find a certain convergence between both tables on the environmental indicators

After the concordance phase, and in agreement with Bouquin's advice ${ }^{4}, 8$ indicators have been selected and agreed. The first seven indicators having being identified by the majority (Cf. Table 3 ), they were naturally

\footnotetext{
${ }^{4}$ A dashboard must have a minimum set of indictors as to be understood and use.
} 
accepted by all subgroups. The eighth indicator (social/societal) was more difficult to define, as it took almost one hour to decide if other indicators were or not added to the set. After a complex discussion, it was decided not to add other indicator. Having more than 9-10 indicators was considered too much by the group. The resulting dashboard can be then declined as follows:

Table 4 - Final dashboard for experts: the key indicators of urban logistics from the standpoint of sustainability

\begin{tabular}{|c|c|c|c|c|c|}
\hline \multirow{2}{*}{ Domains } & \multirow{2}{*}{ Category } & \multirow{2}{*}{ Main indicator $($ total $=8)$} & \multirow{2}{*}{$\begin{array}{l}\text { Correspondence } \\
\text { with Table } 3 .\end{array}$} & \multicolumn{2}{|c|}{ Ranking's consolidator } \\
\hline & & & & Type & tor \\
\hline \multirow{2}{*}{ Economic } & Logistics & Operational costs & Ind. $\mathrm{n}^{\circ} 5$ & Economic & PrA \\
\hline & Audit & Monetary savings & Ind. $n^{\circ} 6$ & Economic & PrA \\
\hline \multirow{3}{*}{ Economic } & \multirow{3}{*}{ Service quality } & Service rates & Ind. $n^{\circ} 1$ & Economic & $\begin{array}{l}\text { PrA \& } \\
\text { FC }\end{array}$ \\
\hline & & Customers' satisfaction rates & Ind. $\mathrm{n}^{\circ} 2$ & Economic & $\begin{array}{l}\text { PrA \& } \\
\text { FC }\end{array}$ \\
\hline & & Customers' evolution & Ind. $\mathrm{n}^{\circ} 7$ & Economic & PrA \\
\hline Environmental & $\begin{array}{c}\text { Environmental } \\
\text { effects }\end{array}$ & Pollution emission rates & Ind. $n^{\circ} 4$ & Environmental & $\begin{array}{c}\text { PrA \& } \\
\text { PuA }\end{array}$ \\
\hline Environmental & $\begin{array}{l}\text { Congestion } \\
\text { reduction }\end{array}$ & Congestion rates & Ind. $n^{\circ} 3$ & Environmental & $\begin{array}{c}\text { PrA \& } \\
\text { PuA }\end{array}$ \\
\hline Social/societal & $\begin{array}{c}\text { Social/societal } \\
\text { effects }\end{array}$ & $\begin{array}{l}\text { Number of employments } \\
\text { created/destroyed/reconverted }\end{array}$ & Ind. $\mathrm{n}^{\circ} 17$ & Social/Societal & $\begin{array}{l}\text { PrA \& } \\
\text { PuAut }\end{array}$ \\
\hline
\end{tabular}

To sum up, we observe that the indicators are in general more specific than those proposed in the literature. The needs imply the definition of detailed indicators that public and/or private stakeholders from both sides can understand. For example, logistics indicators are related to transport loading rates, with and without linking them to the distances traveled. Similarly, such indicators need to be associated with warehousing performance (in terms of loading rates) and with the general financial balance. In this case, for instance, no inventorying performance indicators were calculated due to collaboration with transport carriers or the parties directly associated with them (i.e., mainly $2 \mathrm{PL}$ and $3 \mathrm{PL}$ ), as they make their inventory management decisions themselves.

Environmental indicators showed the importance of greenhouse gas and pollutant emissions. It is noteworthy that noise was not selected because transport and logistics practitioners are less sensitive to societal issues than public authorities. Additionally, gains in less congestion (reduction in the number of trucks, for example) appear as more central for public actors than for private actors. Regarding the social path, the importance of converting the potential number of employees to be shed into new and added-value jobs is also viewed more as a public issue than a private one.

Finally, it is important to note that to evaluate sustainable urban performance, it is necessary to establish/identify a reference grid in terms of key performance indicators in order to respond to the problems faced by professional and private stakeholders, and with members of both parts in attendance.

\section{Conclusion}

The evaluation of urban logistics projects should be seen from the perspective of Sustainable Development. Consequently, three dimensions (economic, environmental and social/societal) must be taken into account. Likewise, it is advisable to enumerate a limited though sufficient number of indicators for decision-making. We proposed a framework based in group decision-making for defining a dashboard to evaluate the sustainability of urban logistics projects, taking into account both public and private stakeholders' visions and viewpoints.

From the economic standpoint, the perspective of private enterprise predominates. Two main groups of economic indicators were evaluated in the different works (dealing equally with the efficiency of the company as a whole and with global logistics in the case of urban goods transport): the macroscopic indicators of a company's economic continuity and the economic performance indicators of logistics. 
Regarding the environmental dimension, the main variables to be studied are the following: energy consumption, variations of pollutant emissions in comparison to an initial situation and to all urban transport emissions (people + goods). Only greenhouse gas emissions as an indicator appear central for professionals, while others elements are considered by public authorities (congestion, noise)

The social/societal dimension is more difficult to characterize and requires more in-depth study. Nonetheless, identifying social/societal factors within the company and variations in the number of jobs and their reassignment appear to be the main variables involved in the search for social and societal indicators.

The interest of this work was to question operational experts. We also notice that the influence of the group modifies the individual decision. The main limit is that this group of experts did not contain a staff of public authorities. If this had been the case, we think that we would have had finally 1 or 2 societal indicators in the final dashboard.

\section{Acknowledgements}

Part of this work was supported by the ANNONA Project, financed by the French National Agency for Research (ANR), in its Sustainable City and Building program. Authors aim to thank André Van Hecke and Florence Usclade for their exchanges on socio-constructive and active methods, as well as to anonymous reviewers for their comments that helped to improve the paper.

\section{References}

Allen, J., Browne, M. (2010). Sustainability strategies for city logistics. In A. McKinnon, S. Cullinane, A. Whiteing \& M. Browne (Eds.), Green Logistics: Improving The Environmental Sustainability of Logistics. New Delhi, India: Kogan Page Limited.

Bazin, S., Beckerich, C. (2008). Le renforcement des contraintes spatiales des entreprises : le transport comme vecteur de valorisation de la prestation logistique, les Cahiers Scientifiques du Transport, $\mathrm{n}^{\circ}$ 54, pp. 49.72.

Bernadet, M. (2008). Introduction au dossier «Transport et logistique durables : vers la nécessaire prise en compte de leur interdépendance », Notes de synthèse du SESP, ${ }^{\circ}$ 168, pp. 5-8.

Blanquart, C., Carbone, V. (2008). La place du transport dans les organisations logistiques durables, les Cahiers Scientifiques du Transport, $\mathrm{n}^{\circ}$ 54, p. 11-24.

Blanquart, C., Burmeister, A. (2009). Evaluating the performance of freight transport: a service approach. European transport research review, 1(3), 135-145.

Carbone, V., Blanquart, C. (2014). Collaborative supply chains and environmental awareness: a typology in terms of "proximity". Supply Chain Forum: An International Journal, to appear.

Bouquin, H. (2001). Le contrôle de gestion, Presses Universitaires de France, Paris, $5^{\text {th }}$ éd.

Carter, C., Rogers, D. (2008). A framework of Sustainable Supply Chain Management: moving toward new theory, International Journal of Physical Distribution \& Logistics Management, 38(5), pp. 360-387.

Collin, M. (2003) (Coord.). Ville portuaire, acteur du développement durable, L’Harmattan.

Csibra, G., Gergely, G. (2009). Natural pedagogy. Trends in cognitive sciences, 13(4), pp. 148-153.

Dablanc, L., Rakotonarivo, D. (2010). The impacts of logistics sprawl: How does the location of parcel transport terminals affect the energy efficiency of goods' movements in Paris and what can we do about it? Procedia-Social and Behavioral Sciences, 2(3), pp.6087-6096.

Gond, J.-P. (2006). Gestion des ressources humaines et Développement Durable. In Reynaud, E. (Eds.), Le Développement Durable au cœur de l'entreprise, Ed. Dunod, pp. 83-116. 
Gonzalez-Feliu, J., Morana, J. (2010). Are City Logistics Solutions Sustainable? The Cityporto case. TeMA. Journal of Land Use, Mobility and Environment, 3(2), pp. 55-64.

Gonzalez-Feliu, J., Durand, B., Andriankaja, D. (2012), Urban logistics and e-grocery: have new B2C trends a positive impact on the environment? In Golinska P., Romano, C.A. (eds.), Environmental issues in Supply Chain Management - new trends and applications, Springer, Heidelberg, pp. 251-264.

Gonzalez-Feliu, J., Morana, J. (2014). Assessing urban logistics pooling sustainability via a hierarchic dashboard from a group decision perspective. In Macharis, C., Melo, S., Woxenius, J., Van Lier, T. (eds.) Sustainable Logistics, Emerald, Series: Transport and Sustainability, 6, pp. 113-135.

Gonzalez-Feliu, J., Morana, J., Salanova Grau, J.M., Ma, T.Y. (2013). Design and scenario assessment for collaborative logistics and freight transport systems, International Journal of Transport Economics, 40(2), pp. 207-240.

Griffis, S.E., Goldsby, T.J., Cooper, M., Closs, D.J. (2007). Aligning logistics performance measures to the information needs of the firm, Journal of Business Logistics, 28(2), pp. 35-56.

Gunasekaran, A., Kobu, B. (2007). Performance measures and metrics in logistics and Supply Chain Management: a review of recent literature (1995-2004) for research and applications, International Journal of Production Research, 45(12), pp. 2819-40.

Lindholm, M. (2013). Urban freight transport from a local authority perspective-a literature review, European Transport/Trasporti Europei, 54(3), pp. 1-37.

Morana, J. (2013). Sustainable Supply Chain Management, London: Wiley-ISTE.

Morana, J., Gonzalez-Feliu, J., Semet, F. (2014). Urban Consolidation and Logistics Pooling. In GonzalezFeliu J., Semet, F., Routhier, J.L. (eds), Sustainable urban logistics: concepts, methods and information systems, Springer, Heidelberg, pp. 187-210.

Mossman, F. H., Morton, N. (1965). Logistics of distribution systems, Allyn and Bacon.

Pagell M., Wu Z. (2009). Building a more complete theory of sustainable Supply Chain Management using case studies of 10 exemplars, Journal of Supply Chain Management, 45(2), p. 37-56.

Patier, D., Browne, M. (2010). A methodology for the evaluation of urban logistics innovations. ProcediaSocial and Behavioral Sciences, 2(3), pp. 6229-6241.

Rodrigue, J. P., Debrie, J., Fremont, A., Gouvernal, E. (2010). Functions and actors of inland ports: European and North American dynamics. Journal of transport geography, 18(4), 519-529.

Ségalou, E., Ambrosini, C., Routhier, J. (2004). The Environmental Assessment of Urban Goods Movement. In Taniguchi, E., Thompson, R.G. (eds.), Logistics Systems for Sustainable Cities, Elsevier, Amsterdam, pp. 207-220.

Seuring, S., Müller M. (2008). From a Literature Review to a Conceptual Framework for Sustainable Supply Chain Management, Journal of Cleaner Production, 16(15), pp. 1699-1710.

Srivastava, S. (2007). Green supply-chain management: a state-of-the-art literature review, International Journal of Management Review, 9(1), pp. 53-80.

Svensson, G. (2007). Aspects of sustainable Supply Chain Management (SSCM): conceptual framework and empirical example, Supply Chain Management: An International Journal, 12(4), pp. 262-266.

Yearwood, J.L., Stranieri, A. (2006). The generic/actual argument model of practical reasoning, Decision support systems, 41, pp. 358-379. 
Appendix 1. Comparison between Table 1. and Table 3.

Table 1. Literature review (Morana et al., 2014)

Table 3. Results of subgroups

\begin{tabular}{|c|c|c|c|}
\hline \multicolumn{2}{|c|}{ Economic indicators $(\mathrm{Nb} .=14)$ concern cost, quality and delay } & \multirow{8}{*}{$\begin{array}{l}\text { 1. Service rate } \\
\text { 2. Customers' satisfaction rate } \\
\text { 5. Operational costs } \\
\text { 6. Monetary savings } \\
\text { 7. Customers' evolution } \\
\text { 8. Vehicles' loading rates } \\
\text { 9. Products' prize }\end{array}$} & \multirow{8}{*}{$\begin{array}{l}\text { 11. Delivery times } \\
\text { 12. Number of deliveries } \\
\text { 13. Average distance per delivery } \\
\text { 16. Logistics reliability }\end{array}$} \\
\hline - Distance travelled (13) & - Investment costs & & \\
\hline - Vehicle load factor (8) & - Operational costs $(5)$ & & \\
\hline - Warehouse load factor & - Return on investment (6) & & \\
\hline • Vehicle load path (8) & - Total travel time & & \\
\hline - Number of parcels at warehouses & - Service rates $(1)$ & & \\
\hline • Number of delivery points & - Delay respect rates (11) & & \\
\hline • Number of collection points (13) & - Customer satisfaction rates (2) & & \\
\hline \multicolumn{2}{|l|}{ Environmental indicators $(\mathrm{Nb} .=6)$} & \multirow{2}{*}{\multicolumn{2}{|c|}{ 3. Congestion }} \\
\hline - Greenhouse gas emission rates (15) & - Noise rates & & \\
\hline - Pollutant gas emission rates (NOx, SOx) (4) & - Road occupancy rates (3) & \multicolumn{2}{|l|}{ 4. Pollution emission rates } \\
\hline - Solid particles emission rates (PM 10) & - Reverse flow rates & \multicolumn{2}{|c|}{ 15. Greenhouse gas emission rates } \\
\hline \multicolumn{2}{|l|}{ Social/Societal indicators $(\mathbf{N b} .=8)$} & \multirow{5}{*}{\multicolumn{2}{|c|}{$\begin{array}{l}\text { 10. Staff turnover } \\
\text { 14. Employees' satisfaction rates } \\
\text { 17. Number of employments created/destroyed/reconverted }\end{array}$}} \\
\hline - Absenteeism rates & - Employment creation rates $(17)$ & & \\
\hline - Stress management rates & - Employment conversion rates (10) & & \\
\hline • Users' acceptability & - Training rates & & \\
\hline - Inhabitant satisfaction rates & • Estimation of city’s image & & \\
\hline
\end{tabular}

Legend: in italic, indicators which partially converge 